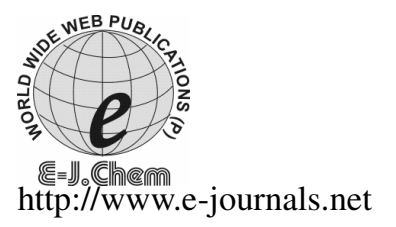

ISSN: 0973-4945; CODEN ECJHAO

E-Journal of Chemistry

2011, 8(2), 727-738

\title{
Formation of the River Water Chemistry in the Middle Section of Dousitu River, China
}

\author{
QIAN HUI, LI PEIYUE, DING JIA, YANG CHAO and ZHANG XUEDI \\ School of Environmental Science and Engineering \\ Chang'an University, Xi'an, Shaanxi, 710054, China \\ qianhuixa@163.com
}

Received 19 July 2010; Accepted 5 September 2010

\begin{abstract}
On basis of hydrogeology of the study area, the characteristics of chemistry of river water and groundwater were analyzed. Analysis results of three river water samples $\left(B_{3}, B_{4}\right.$ and $\left.B_{5}\right)$ collected in the middle section of Dousitu River show the TDS increases from $\mathrm{B}_{3}$ to $\mathrm{B}_{4}$ and decreases from $\mathrm{B}_{4}$ to $\mathrm{B}_{5}$. The concentrations of $\mathrm{Cl}^{-}, \mathrm{Na}^{+}, \mathrm{K}^{+}, \mathrm{Mg}^{2+}$ and $\mathrm{HCO}_{3}{ }^{-}$have a similar change with TDS, but the concentrations of $\mathrm{Ca}^{2+}$ and $\mathrm{SO}_{4}{ }^{2-}$ increase steadily along flow path. The chemical types of the river water change from $\mathrm{HCO}_{3} \cdot \mathrm{Cl}-\mathrm{Na}$ to $\mathrm{Cl} \cdot \mathrm{SO}_{4} \cdot \mathrm{HCO}_{3}-\mathrm{Na}$, and finally to $\mathrm{SO}_{4} \cdot \mathrm{Cl}-\mathrm{Na}$. The causes of these changes are analyzed and studied in depth using various methods. Results indicate river water evaporation, dissolution/precipitation of minerals, cation exchange and mixing of different waters all play important roles in the formation of the river water chemistry. But in different sections of the river, the main processes are different. The study shows that when a reservoir is built in arid areas, the loss of water resources due to evaporation is huge, which can lead to the degradation of water qualities. Hence, great care should be taken to build a reservoir in arid or semi-arid regions.
\end{abstract}

Keywords: Hydrochemistry, Evaporation, Dissolution, Precipitation, Groundwater-surface water relations, Hydrochemical modeling

\section{Introduction}

The formation of river water chemistry has always been the hot topic in hydrology and hydrogeology. It is of great importance to study the formation and evolution of river water chemistry for the purpose of river water quality protection and river ecology protection. Many hydrologists and hydrogeologists around the world have done some significant studies in this interesting and important field. Ronald J. Gibbs ${ }^{1}$ studied the water chemistry data of the Amazon River in 1972. In his study, he recalculated the mean dissolved salts concentration. The calculated results showed that the mean dissolved salts concentration is 11 percent lower than previous calculations for South American rivers and 2.6 percent lower 
than previous calculations for the rivers of the world. Rothwell et al. ${ }^{2}$ studied the spatial and seasonal patterns of river water chemistry at approximately 800 sites in Northwest England and found that there is a clear distinction between the uplands and lowlands in water quality. Upland waters are acidic and have low concentrations of base cations, explained by background geological sources and land cover, while in the lowlands, both past and present human activities have a major impact on river water chemistry. Hein $\mathrm{H}$. van Kleef et al. ${ }^{3}$ studied the changes caused by reduced acidifying deposition in 68 Dutch moorland pools in 2010. Smolders et $a l^{4}$ revealed the intra-annual variability of the major ion composition of the Pilcomayo River, and its relationship to discharge. There are many more scientists ${ }^{5-9}$ paying their attention to the river chemistry study from various aspects all over the world.

Dousitu River is one of the tributaries of the Yellow River. The source of the river is near Etuok County of Inner Mongolia, China. It flows from east to west and intersects the Yellow River near Xinjian Yidui (Figure 1). The length of the river is $166 \mathrm{~km}$, and the drainage area is $4160 \mathrm{~km}^{2}$. The average annual ${ }^{10}$ runoff of the river is $1264 \times 10^{4} \mathrm{~m}$.

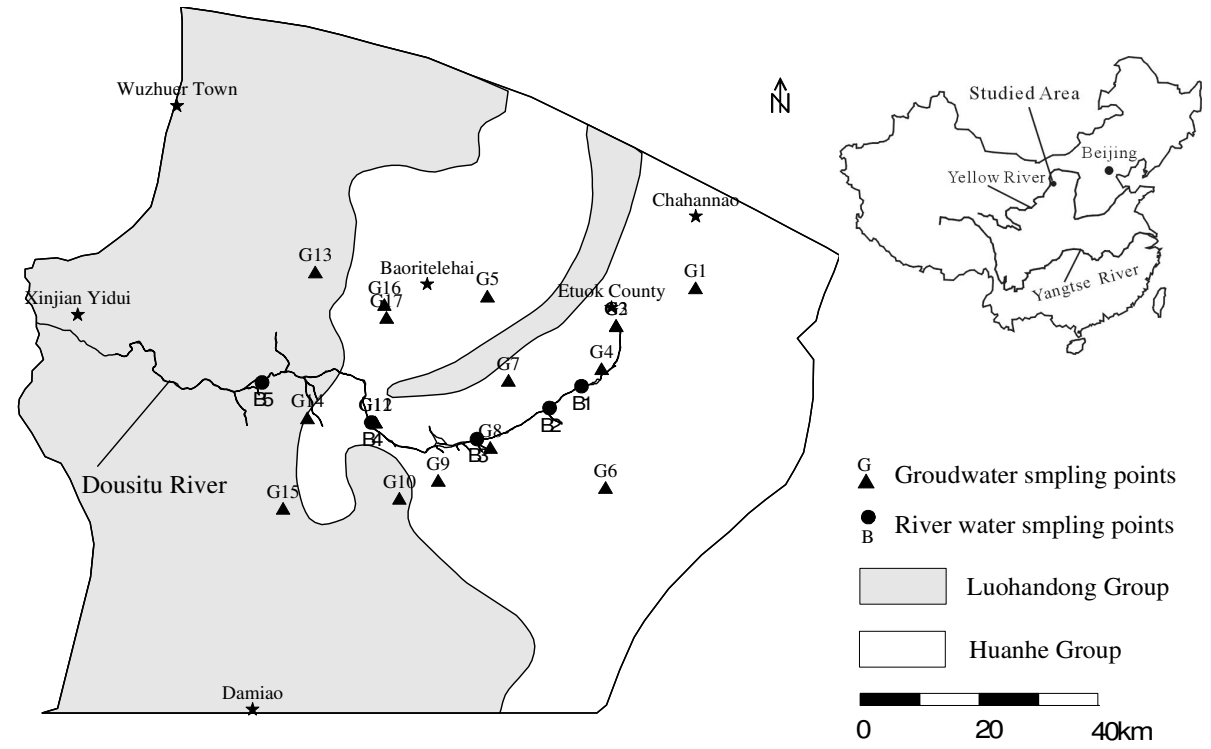

Figure 1. Location of the study area and the sampling position

The Dousitu River drainage basin is situated in an arid area of north-western China. The main characteristics of the climate are a long and cold winter as well as a short and warm summer. According to the monitoring data in Etuok County, the annual temperature in the area changes from 5.3 to $8.9^{\circ} \mathrm{C}$ and has an average value of $6.9{ }^{\circ} \mathrm{C}$. The precipitation mainly occurs between June and August. The annual precipitation ranges from $125.2 \mathrm{~mm}$ to 611.6 $\mathrm{mm}$, and has an average value of $267.5 \mathrm{~mm}$. Evaporation is intensive, and the intensity is between 1947.7 and $2494.9 \mathrm{~mm}$.

In the middle section of Dousitu River $\left(B_{3}\right.$ to $B_{5}$ in Figure 1$)$, the changes of the chemistry of river water are interesting. The TDS of the river water increases from $\mathrm{B}_{3}$ to $\mathrm{B}_{4}$, but decreases from $\mathrm{B}_{4}$ to $\mathrm{B}_{5}$. The concentration of $\mathrm{Cl}^{-}, \mathrm{Na}^{+}, \mathrm{K}^{+}, \mathrm{Mg}^{2+}$ and $\mathrm{HCO}_{3}^{-}$has a similar change with TDS, but the concentration of $\mathrm{Ca}^{2+}$ and $\mathrm{SO}_{4}{ }^{2-}$ increases steadily from $\mathrm{B}_{3}$ to $\mathrm{B}_{5}$. Accordingly, the chemical type of river water changes from $\mathrm{HCO}_{3} \bullet \mathrm{Cl}-\mathrm{Na}$ to $\mathrm{SO}_{4} \bullet \mathrm{Cl}-\mathrm{Na}$. 
What are the reasons for the changes of the chemistry of the river water? What recharge and discharge relationship between river water and groundwater can be drawn from these changes? This paper gives a detailed analysis.

\section{Method}

\section{Geology and Hydrogeology}

In recent years, much research work has been done in Ordos Cretaceous Artesan Basin $(\mathrm{CAB})^{11-14}$. Based on the hydrogeolology, recharge and discharge characteristics of groundwater, $\mathrm{CAB}$ can be divided into 5 groundwater flow systems ${ }^{15,16}$. Dousitu River drainage basin is one of them. According to the lithology and geological age of the strata, the aquifers in the Dousitu River drainage basin can be divided into four groups ${ }^{16-18}$. From the top down, they are the Cenozoic group, the Luohandong group, the Huanhe group and the Luohe group, respectively. There is no continuous aquitard between these aquifers ${ }^{18,19}$.

The Cenozoic group is composed of Tertiary and Quaternary strata. The lithology of the Quaternary stratum, which covers the whole studied area, is mainly composed of fine sand of wind, flood or river deposition, with a light yellow or grey color. The lithology of the Tertiary strata is mainly sandstone and mudstone, rich in gypsum and other easily dissolving salts. It occurs primarily in the western part of the studied area (Figure 1).

The Luohandong group occurs mainly in the western part of the studied area (Figure 1). In most parts of the area, it is overlain by Tertiary stratum. It is a set of continental clastic rocks of early Cretaceous age. The maximum thickness of the formation in the region is more than $200 \mathrm{~m}$. The lithology is primarily sandstone, coarse sandstone interbeded by fine sandstone, conglomerate, and sandy gravel.

The Huanhe group exists in the whole studied area (Figure 1). In the eastern part, apart from a few outcrops, the group is overlain by Quaternary stratum. In the western part, the Huanhe group is overlain by the Luohandong group. The Huanhe group is also a set of continental clastic rock formed in the early Cretaceous period. The maximum thickness of the group in the region is more than $500 \mathrm{~m}$. The lithology is primarily conglomerate, sandy gravel, sandstone and becomes finer downward.

The Luohe group does not outcrop in the studied area. It is overlain by the Huanhe group in the whole region. The lithology of the group is mainly continental clastic rock of sandstone, mudstone, conglomerate and sandy gravel formed in the early Cretaceous period. The maximum thickness of the group in the region is more than $300 \mathrm{~m}$.

In the Dousitu River drainage basin, groundwater is mainly recharged by precipitation. In the horizontal direction, the groundwater in all the aquifers of the north bank flows from north-east to south-west, and the groundwater in all the aquifers of south bank flows from south-east to north-west ${ }^{20}$. In the vertical direction, the level of shallow groundwater in eastern part of the study area is higher than that of deep groundwater, so the water flows downward, whereas the level of deep groundwater in the western part of the study area is higher than that of shallow groundwater and the water flows upward. The discharge of groundwater in the region is mainly to the Dousitu River, pumping for irrigation, and drinking as well as the outflow to western boundary.

\section{Chemical characteristics of river water and groundwater}

To study the chemistry of river water and groundwater, 22 water samples including 5 river water samples and 17 groundwater samples were collected (in September 2004) for chemical analysis. Table 1 lists the chemical analysis results. In the table, $G_{1} \sim G_{17}$ are groundwater, $B_{1} \sim B_{5}$ are river water. $\mathrm{SI}_{\mathrm{cal}} \mathrm{SI}_{\mathrm{gyp}}$, and $\mathrm{SI}_{\mathrm{dol}}$ are the saturation indices of calcite, gypsum and dolomite, respectively. 
Table 1. Chemical analysis results of Dousitu river water and nearby groundwater (Unit: $\mathrm{mg} / \mathrm{L}$ )

\begin{tabular}{|c|c|c|c|c|c|c|c|c|c|c|c|c|c|c|}
\hline Sample No. & Aquifer & TDS & $\mathrm{pH}$ & $\mathrm{Na}^{+}$ & $\mathrm{K}^{+}$ & $\mathrm{Ca}^{2+}$ & $\mathrm{Mg}^{2+}$ & $\mathrm{Cl}^{-}$ & $\mathrm{SO}_{4}{ }^{2-}$ & $\mathrm{HCO}_{3}^{-}$ & $\mathrm{CO}_{3}{ }^{2-}$ & $\mathrm{SI}_{\mathrm{cal}}$ & $\mathrm{SI}_{\mathrm{dol}}$ & $S I_{\text {gyp }}$ \\
\hline $\mathrm{G}_{1}$ & Huanhe & 327.53 & 7.7 & \multicolumn{2}{|c|}{23.11} & 60.96 & 25.34 & 42.79 & 35.54 & 155.05 & 0 & -0.019 & -0.381 & -2.044 \\
\hline $\mathrm{G}_{2}$ & Huanhe & 629.77 & 8.025 & \multicolumn{2}{|c|}{130.23} & 47.095 & 26.745 & 40.415 & 44.43 & 358.475 & 0 & 0.526 & 0.843 & -2.114 \\
\hline $\mathrm{G}_{3}$ & Huanhe & 592.56 & 7.6 & \multicolumn{2}{|c|}{125.2} & 44.1 & 29.2 & 39 & 76.8 & 341.7 & 0 & 0.034 & -0.075 & -1.91 \\
\hline $\mathrm{G}_{4}$ & Huanhe & 524.36 & 7.7 & \multicolumn{2}{|c|}{184} & 15.03 & 4.38 & 145 & 95.1 & 161.7 & 0 & -0.636 & -1.771 & -2.233 \\
\hline $\mathrm{B}_{1}$ & River & 606.07 & 8.3 & 190 & 3.65 & 21 & 17.1 & 83.6 & 95.6 & 357 & 6 & 0.441 & 0.828 & -2.14 \\
\hline $\mathrm{B}_{2}$ & River & 619.18 & 8.4 & 190 & 4.55 & 26.1 & 8.3 & 99.3 & 121.5 & 308.1 & 9 & 0.574 & 0.685 & -1.939 \\
\hline $\mathrm{G}_{5}$ & Huanhe & 362.15 & 7.7 & \multicolumn{2}{|c|}{99.8} & 21.4 & 12.3 & 44 & 59.6 & 222.1 & 0 & -0.318 & -0.842 & -2.248 \\
\hline $\mathrm{G}_{6}$ & Huanhe & 268.17 & 7.4 & \multicolumn{2}{|c|}{22.5} & 52.1 & 5.5 & 16 & 40.8 & 115.9 & 0 & -0.5 & -1.942 & -1.982 \\
\hline $\mathrm{G}_{7}$ & Huanhe & 384.71 & 8.4 & \multicolumn{2}{|c|}{83.62} & 36.37 & 19.5 & 62.47 & 64.22 & 158.83 & 6.24 & 0.481 & 0.729 & -2.015 \\
\hline $\mathrm{G}_{8}$ & Huanhe & 243.57 & 8.8 & \multicolumn{2}{|c|}{95.6} & 2.81 & 0.36 & 32.98 & 40.83 & 129.97 & 12 & -0.254 & -1.364 & -3.224 \\
\hline $\mathrm{B}_{3}$ & River & 755.12 & 8.4 & 250 & 5.45 & 22 & 13.1 & 122.3 & 145.5 & 363.1 & 12 & 0.547 & 0.905 & -1.974 \\
\hline $\mathrm{G}_{9}$ & Cenozoic & 461.62 & 7.6 & \multicolumn{2}{|c|}{77.17} & 21.91 & 56.97 & 47.03 & 55.83 & 405.42 & 0 & -0.198 & 0.055 & -2.368 \\
\hline $\mathrm{G}_{10}$ & Huanhe & 566.53 & 7.6 & \multicolumn{2}{|c|}{189} & 16.89 & 13.84 & 109.92 & 132.56 & 206.64 & 0 & -0.603 & -1.259 & -2.072 \\
\hline $\mathrm{G}_{11}$ & Huanhe & 525.02 & 8.85 & \multicolumn{2}{|c|}{170.4} & 16.5 & 0 & 80.7 & 205.3 & 98.55 & 3.6 & 0.334 & -8.519 & -1.884 \\
\hline $\mathrm{G}_{12}$ & Luohe & 905.74 & 8.1 & \multicolumn{2}{|c|}{244.8} & 61.1 & 0.6 & 76.2 & 492.8 & 59.8 & 0 & -0.156 & -2.295 & -1.067 \\
\hline $\mathrm{B}_{4}$ & River & 2922.74 & 8.3 & 1010 & 18.5 & 26.1 & 47.1 & 616.8 & 734.9 & 912.2 & 9 & 0.699 & 1.69 & -1.532 \\
\hline $\mathrm{G}_{13}$ & Luohandong & 576.13 & 8 & \multicolumn{2}{|c|}{93.45} & 72.37 & 29.67 & 160.33 & 136.25 & 168.12 & 0 & 0.334 & 0.318 & -1.483 \\
\hline $\mathrm{G}_{14}$ & Luohandong 2 & 2656.725 & 7.87 & \multicolumn{2}{|c|}{856.755} & 54.91 & 100.4 & 722.355 & 546.195 & 554.34 & 0 & 0.403 & 1.11 & -1.315 \\
\hline $\mathrm{G}_{15}$ & Luohandong & 748.345 & 7.92 & \multicolumn{2}{|c|}{213.24} & 17.535 & 24.31 & 148.015 & 199.815 & 226.675 & 0 & -0.249 & -0.322 & -1.935 \\
\hline $\mathrm{G}_{16}$ & Huanhe & 703.17 & 7.5 & \multicolumn{2}{|c|}{146.23} & 51.04 & 36.56 & 129.16 & 140.11 & 203.8 & 0 & -0.257 & -0.622 & -1.627 \\
\hline $\mathrm{G}_{17}$ & Huanhe & 1095.4 & 8 & \multicolumn{2}{|c|}{273.01} & 70.41 & 46.29 & 379.48 & 184.51 & 283.4 & 0 & 0.484 & 0.825 & -1.47 \\
\hline $\mathrm{B}_{5}$ & River & 1854.52 & 8.1 & 535 & 3.65 & 66.1 & 15.6 & 352.7 & 780.5 & 170.9 & 3 & 0.247 & -0.104 & -0.987 \\
\hline
\end{tabular}


The sampling location of these water samples is shown in Figure 1. The water samples in Table 1 are put along the flow direction. For example, the water samples before $B_{1}$ in Table 1 are in the upper part of $B_{1}$, the water samples between $B_{2}$ and $B_{3}$ are in the upper part of $B_{3}$ and lower part of $\mathrm{B}_{2}$.

Figure 2 shows the changes of TDS and concentrations of major species in river water along the flow path. It can be seen from the figure that the TDS and the concentrations of major species in river water remain basically unchanged from $B_{1}$ to $B_{3}$. From $B_{3}$ to $B_{4}$, except the concentration of $\mathrm{Ca}^{2+}$, TDS and concentrations of other species increase greatly. From $\mathrm{B}_{4}$ to $\mathrm{B}_{5}$, except the concentrations of $\mathrm{Ca}^{2+}$ and $\mathrm{SO}_{4}{ }^{2-}$, TDS and concentrations of other species decrease to some extent.
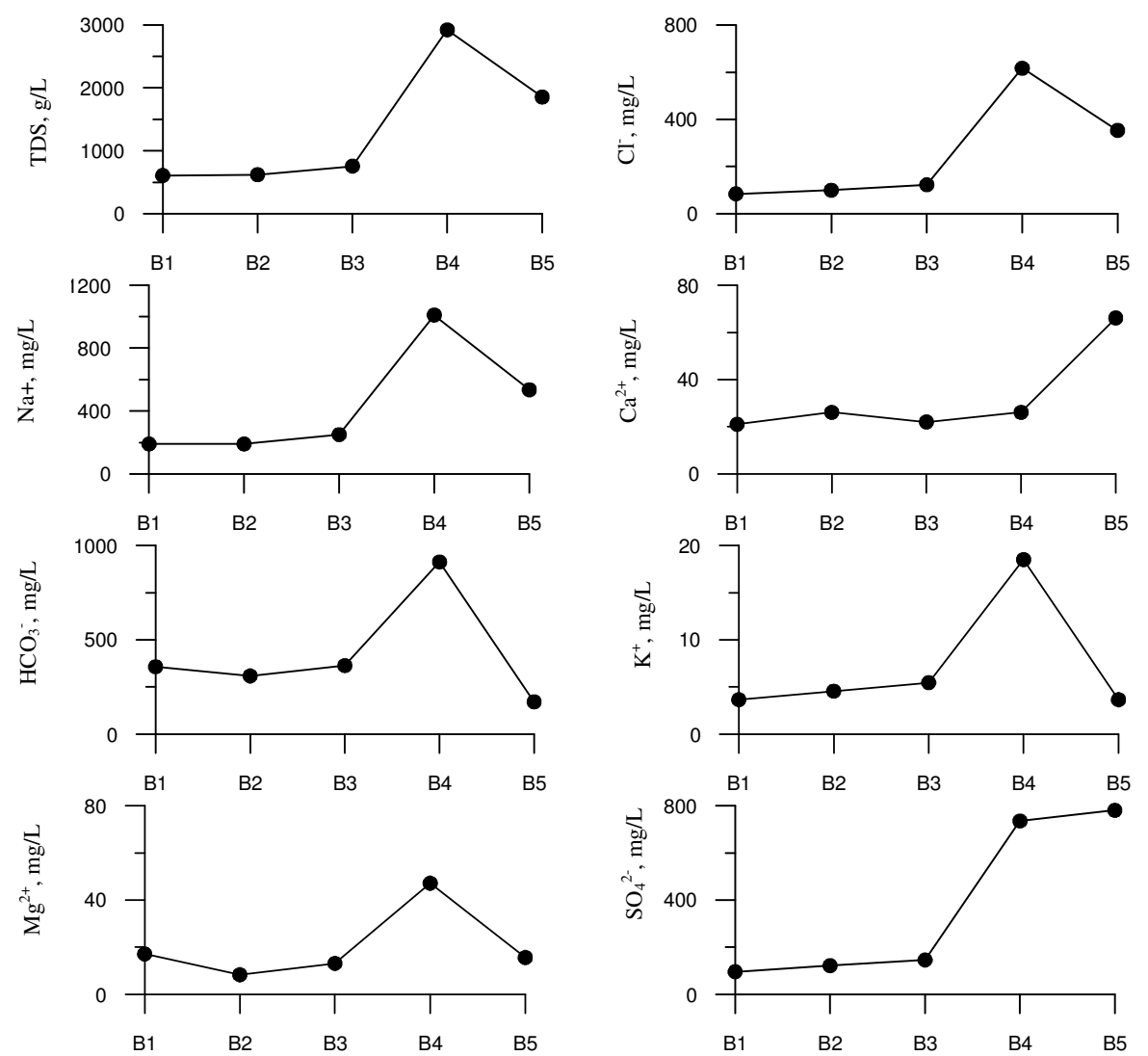

Figure 2. Changes of TDS and concentrations of major species along flow path

Figure 3 shows the changes of concentration of major cations and anions in meq\% along the flow path. Similarly, from $\mathrm{B}_{1}$ to $\mathrm{B}_{3}$, the concentration of all the species in meq $\%$ is relatively steady. The concentration of $\mathrm{Na}^{+}$in meq $\%$ is greater than $75 \%$ for all the river waters and is obviously the primary species of all the cations. By contrast, the changes of the concentration of anions in meq $\%$ are relatively large. From $\mathrm{B}_{1}$ to $\mathrm{B}_{5}, \mathrm{HCO}_{3}{ }^{-}$in meq $\%$ decreases while $\mathrm{Cl}^{-}$and $\mathrm{SO}_{4}{ }^{2-}$ in meq\% increase. The main anion in $\mathrm{B}_{1}, \mathrm{~B}_{2}$ and $\mathrm{B}_{3}$ is $\mathrm{HCO}_{3}{ }^{-}$, $\mathrm{Cl}^{-}$and $\mathrm{SO}_{4}{ }^{2-}$ rank second and third respectively. From $\mathrm{B}_{4}$ to $\mathrm{B}_{5}$, the main anions change from $\mathrm{HCO}_{3}{ }^{-}$to $\mathrm{Cl}^{-}$and $\mathrm{SO}_{4}{ }^{2-}$. So the chemical type of river water in $\mathrm{B}_{1}, \mathrm{~B}_{2}$, and $\mathrm{B}_{3}$ is $\mathrm{HCO}_{3}{ }^{-}$ $\mathrm{Na}$ or $\mathrm{HCO}_{3} \bullet \mathrm{Cl}-\mathrm{Na}$, in $\mathrm{B}_{4}$ it changes to $\mathrm{Cl} \bullet \mathrm{SO}_{4} \bullet \mathrm{HCO}_{3}-\mathrm{Na}$, in $\mathrm{B}_{5}$, it becomes $\mathrm{SO}_{4} \bullet \mathrm{Cl}-\mathrm{Na}$. 


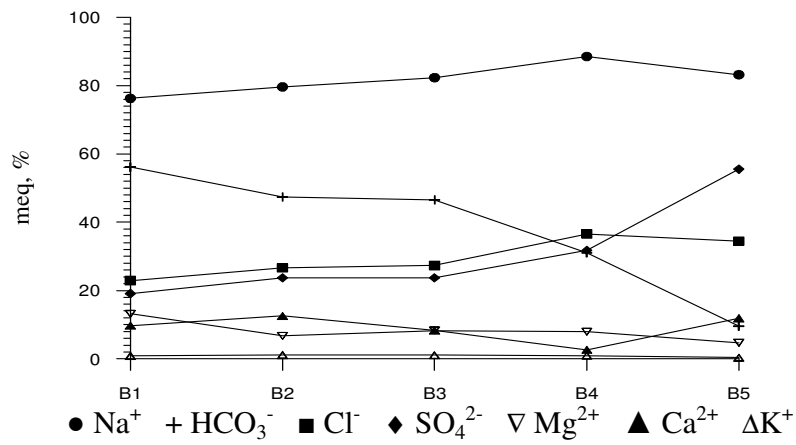

Figure 3. Changes of concentration of major species in meq\% along flow path

Figure 4 shows the changes of the saturation indices of calcite, dolomite and gypsum along the flow direction. It can be seen that all the river waters is undersaturated with respect to gypsum, although its saturation index increases steadily along the flow path. For calcite and dolomite, except dolomite is slightly undersaturated in $\mathrm{B}_{5}$, all the other river waters are supersaturated with respect to the minerals.

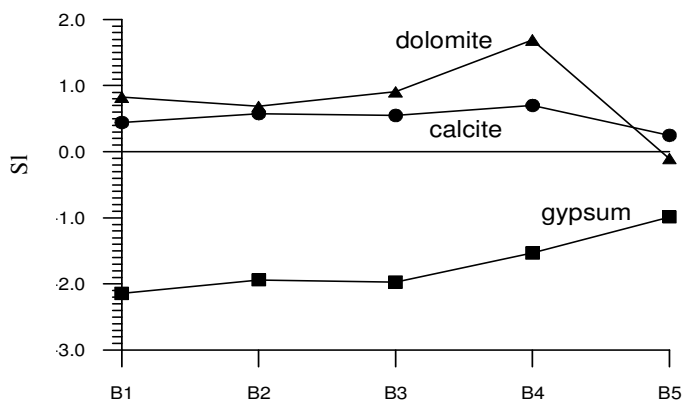

Figure 4. Changes of saturation indices of major minerals along flow path

Figure 5 is the Piper diagram for all the waters samples in the study area, it is obvious that groundwater is mainly $\mathrm{HCO}_{3} \cdot \mathrm{Cl}-\mathrm{Na}(\mathrm{Ca}, \mathrm{Mg})$, except $\mathrm{G}_{11}$ and $\mathrm{G}_{12}$ are $\mathrm{SO}_{4} \cdot \mathrm{Cl}-\mathrm{Na}$, and $\mathrm{SO}_{4}$ $\mathrm{Na} \cdot \mathrm{Ca}$, respectively. The TDS of groundwater has an increasing trend from the upper reaches to the lower reaches. As has been said before, in the upper reaches, the river water is mainly $\mathrm{HCO}_{3} \bullet \mathrm{Cl}-\mathrm{Na}$, towards the lower reaches, it changes to $\mathrm{Cl} \bullet \mathrm{SO}_{4} \bullet \mathrm{HCO}_{3}-\mathrm{Na}$ and $\mathrm{SO}_{4} \cdot \mathrm{Cl}-\mathrm{Na}$.

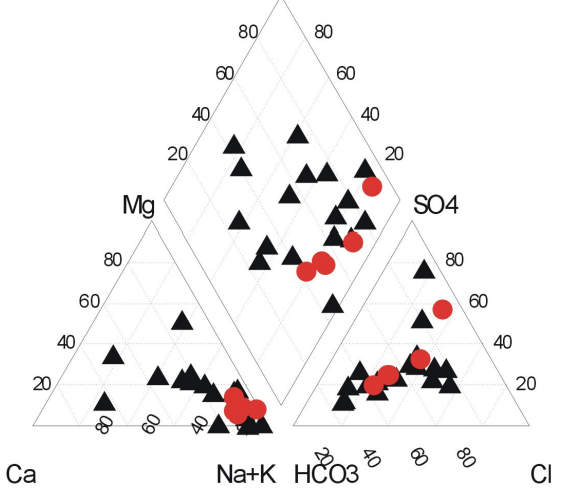

Figure 5. Piper diagram for the water samples in the study area

$\Delta$ Groundwater $\bullet$ River water 
From the above discussion we know the major changes of the chemistry of river water occurred between $\mathrm{B}_{3}$ to $\mathrm{B}_{5}$, which is in the middle section of the Dousitu River. So the river in this section is divided into two parts for the study, which are $\mathrm{B}_{3}-\mathrm{B}_{4}$ and $\mathrm{B}_{4}-\mathrm{B}_{5}$, respectively.

\section{Water chemistry changes from $B_{3}$ to $B_{4}$}

From $\mathrm{B}_{3}$ to $\mathrm{B}_{4}$, the TDS and concentration of major species in river water increase to different degrees. According to field investigation, a dam was built in $\mathrm{B}_{4}$ in 1978. Though the dam is only $20 \mathrm{~m}$ high, it forms an open water surface of about $4.5 \mathrm{~km}^{2}$. The direct result is the intensive evaporation of river water. Furthermore, the samples collected on 8 9 September, 2004 has experienced intensive evaporation during the whole summer. So the increase of TDS and concentration in $\mathrm{B}_{4}$ is understandable. Further analysis of the chemistry of river water from $\mathrm{B}_{3}$ to $\mathrm{B}_{4}$ indicates the increase is different for different species. The concentrations of $\mathrm{Cl}^{-}, \mathrm{SO}_{4}{ }^{2-}, \mathrm{Na}^{+}, \mathrm{Mg}^{2+}, \mathrm{K}^{+}$and TDS in $\mathrm{B}_{4}$ are 5.04, 5.05, 4.04, 3.6, 3.39 and 3.87 times of that in $\mathrm{B}_{3}$, respectively. While the increases of $\mathrm{Ca}^{2+}$ and $\mathrm{HCO}_{3}{ }^{-}$are relatively small, and their concentrations in $\mathrm{B}_{4}$ are only 1.19 and 2.51 times of that in $\mathrm{B}_{3}$.

The river water in $\mathrm{B}_{4}$ is mainly recharged by upstream river water and groundwater. Because the chemistry of river water and groundwater in the upper part of $\mathrm{B}_{4}$ are similar, the river water in $\mathrm{B}_{3}$ is used as the recharging water to analyze the formation of the chemistry of river water in $\mathrm{B}_{4}$.

\section{Estimation of evaporation proportion}

If there were no effects of chemical reactions, the increase rate of the concentrations of various species should be same under the sole influence of evaporation. The above-mentioned different concentration increase rates for different species indicates the formation of the river water chemistry in $\mathrm{B}_{4}$ has been affected by some chemical reactions. For the following reasons, the main reactions are the dissolution of gypsum and halite, as well as the precipitation of calcite.

(1) The study area is located in the arid region, the Tertiary stratum scattered in the area contains large amount of gypsum and halite. The river water in the area is all undersaturated with respect to these minerals.

(2) River water in $\mathrm{B}_{3}$ and $\mathrm{B}_{4}$ is supersaturated with respect to calcite, and the concentration increase rates of $\mathrm{Ca}^{2+}$ and $\mathrm{HCO}_{3}^{-}$are apparently smaller than that of $\mathrm{Cl}^{-}, \mathrm{SO}_{4}{ }^{2-}, \mathrm{Na}^{+}$, $\mathrm{Mg}^{2+}$ and $\mathrm{K}^{+}$. Where have the $\mathrm{Ca}^{2+}$ and $\mathrm{HCO}_{3}{ }^{-}$gone during the process of evaporation? Precipitation of calcite is the natural answer.

To estimate the evaporation proportion during the formation of river water chemistry in $\mathrm{B}_{4}$, the effects of chemical reactions to the changes of the concentrations of various species should be analyzed first. Because of the dissolution of halite, the concentrations of $\mathrm{Cl}^{-}$and $\mathrm{Na}^{+}$will increase on the basis of evaporation. So under the sole influence of evaporation, the concentration increase rates of $\mathrm{Cl}^{-}$and $\mathrm{Na}^{+}$from $\mathrm{B}_{3}$ to $\mathrm{B}_{4}$ should be smaller than the present values of 5.04 and 4.04. In other words, evaporation proportion estimated by the concentration increase rates of $\mathrm{Cl}^{-}$and $\mathrm{Na}^{+}$will be larger than the real value, although we do not know this value up to now. Because of the dissolution of gypsum, evaporation proportion estimated by the concentration increase rate of $\mathrm{SO}_{4}{ }^{2-}$ will also be too large. Compared with the above species, estimates based on the increase rates of $\mathrm{Ca}^{2+}$ and $\mathrm{HCO}_{3}^{-}$ (1.19 and 2.51, respectively) are smaller than the real value because of the precipitation of calcite. Since the precipitation of calcite is mainly caused by the dissolution of gypsum, the contribution of dissolution of gypsum and halite to the increase of TDS is lager than the decrease caused by the precipitation of calcite. Therefore the evaporation proportion estimated by the increase rate of TDS (3.87) is also larger than the real value. Through the above 
analysis, the increase rate caused solely by evaporation should be in the range of 2.51 to 3.87 . Considering the increase rates of $\mathrm{Mg}^{2+}$ and $\mathrm{K}^{+}$(3.6 and 3.39, respectively), the average value of their increase rates is used to estimate the effects of sole evaporation. That is to say, in the process of formation of the chemistry of river water from $\mathrm{B}_{3}$ to $\mathrm{B}_{4}$, the concentration increase rate caused solely by evaporation is 3.5 , or the evaporation proportion in $\mathrm{B}_{4}$ is $71.43 \%$.

\section{Reactions forming the chemistry of river water in $B_{4}$}

The chemistry of river water in $\mathrm{B}_{3}, \mathrm{~B}_{4}$ and the residual water after evaporation (WAE) by the above proportion are compared in Table 2 . It is clear although the chemistry of WAE is close to the river water in $\mathrm{B}_{4}$, but the two have distinct differences. These differences are mainly caused by chemical reactions. According to the saturation indices in Figure 4, halite and gypsum are under saturated in $\mathrm{B}_{3}$ and $\mathrm{B}_{4}$, while calcite is supersaturated. So the main reactions forming the chemistry of $\mathrm{B}_{4}$ are thought to be the dissolution of halite and gypsum, the precipitation of calcite and degassing of $\mathrm{CO}_{2}$, the later is the common reaction accompanying the precipitation of calcite.

Table 2 Comparison of the water chemistry of $\mathrm{B}_{4,} \mathrm{~B}_{3}$ and WAE (Unit: $\mathrm{mg} / \mathrm{L}$ )

\begin{tabular}{|c|c|c|c|c|c|c|c|c|c|}
\hline No. & TDS & $\mathrm{Na}^{+}$ & $\mathrm{K}^{+}$ & $\mathrm{Ca}^{2+}$ & $\mathrm{Mg}^{2+}$ & $\mathrm{Cl}^{-}$ & $\mathrm{SO}_{4}^{2-}$ & $\mathrm{HCO}_{3}{ }^{-}$ & $\mathrm{CO}_{3}{ }^{2-}$ \\
\hline $\mathrm{B}_{3}$ & 755.12 & 250 & 5.45 & 22 & 13.1 & 122.3 & 145.5 & 363.1 & 12 \\
\hline WAE & 2642.92 & 875 & 19.08 & 77 & 45.85 & 428.05 & 509.25 & 1270.85 & 42 \\
\hline $\mathrm{B}_{4}$ & 2922.74 & 1010 & 18.50 & 26.1 & 47.1 & 616.8 & 734.9 & 912.2 & 9 \\
\hline \multicolumn{9}{|c|}{$\begin{aligned} \mathrm{NaCl} & =\mathrm{Cl}^{-}+\mathrm{Na}^{+} \\
\mathrm{CaSO}_{4} & =\mathrm{SO}_{4}^{2-}+\mathrm{Ca}^{2+} \\
\mathrm{O}_{3}^{2-}+\mathrm{Ca}^{2+} & =\mathrm{CaCO}_{3} \\
\mathrm{H}_{2} \mathrm{CO}_{3} & =\mathrm{CO}_{2}+\mathrm{H}_{2} \mathrm{O}\end{aligned}$} & $\begin{array}{l}\text { (1) } \\
(2) \\
(3) \\
(4)\end{array}$ \\
\hline
\end{tabular}

At the same time, because the dissolution of halite can not solely explain the increase of $\mathrm{Na}^{+}$in $\mathrm{B}_{4}$ and the concentration of $\mathrm{Mg}^{2+}$ increased in $\mathrm{B}_{4}$ compared with $\mathrm{B}_{3}$. Considering the flow rate of river water decreased a lot in $\mathrm{B}_{4}$ because of the building of the reservoir and a thick layer of fine deposits formed in the reservoir bottom. So the above changes of the cation concentration are explained by the following reactions.

$$
\begin{gathered}
\mathrm{K}^{+}+\mathrm{NaX}=\mathrm{Na}^{+}+\mathrm{KX} \\
\mathrm{Ca}^{2+}+2 \mathrm{NaX}=2 \mathrm{Na}^{+}+\mathrm{CaX}_{2} \\
\mathrm{Ca}^{2+}+\mathrm{MgX}=\mathrm{Mg}^{2+}+\mathrm{CaX}
\end{gathered}
$$

The method of mass balance is used to calculate the amount of chemical reactions (1) (7) during the formation of the chemistry of river water in $\mathrm{B}_{4}$ from WAE. Table 3 lists the calculated results. In the table, the amounts of chemical reactions $(5) \sim(7)$ are denoted by adsorbed amount of $\mathrm{K}^{+}, \mathrm{Ca}^{2+}$ and $\mathrm{Ca}^{2+}$, respectively. The calculated results in Table 3 confirmed the qualitative guess. That is during the formation of chemistry of river water in $\mathrm{B}_{4}$ from WAE, the dissolution of halite and gypsum, the precipitation of calcite and the degassing of $\mathrm{CO}_{2}$ are the main reactions. Cation exchanges between $\mathrm{K}^{+}$and $\mathrm{Na}^{+}, \mathrm{Ca}^{2+}$ and $\mathrm{Na}^{+}$and $\mathrm{Ca}^{2+}$ and $\mathrm{Mg}^{2+}$ also play certain roles.

Table 3. Results of chemical reactions in $\mathrm{B}_{4}$ from WAE (Unit: $\mathrm{mmol} / \mathrm{L}$ )

\begin{tabular}{ccccccc}
\hline$(1)$ & $(2)$ & $(3)$ & $(4)$ & $(5)$ & $(6)$ & $(7)$ \\
\hline 5.39 & 2.35 & -3.33 & -3.09 & $-0.01\left(\mathrm{~K}^{+}\right)$ & $-0.24\left(\mathrm{Ca}^{2+}\right)$ & $-0.05\left(\mathrm{Ca}^{2+}\right)$ \\
\hline
\end{tabular}

In fact, during the processes of the formation of the chemistry of river water in $\mathrm{B}_{4}$, mineral dissolution and precipitation, cation exchange and evaporation occur at the same time. But evaporation is the main process, which caused the subsequent chemical reactions. The two is separated for the convenience of analysis in our discussion. 


\section{Water chemistry changes from $B_{4}$ to $B_{5}$}

The changes of the concentrations of major ions with TDS for $\mathrm{B}_{4}, \mathrm{~B}_{5}$ and the groundwater between them are shown in Figure 6. It can be seen clearly from the figure that for the nonreactive ions such as $\mathrm{Cl}^{-}$and $\mathrm{Na}^{+}+\mathrm{K}^{+}$, the chemistry of river water in $\mathrm{B}_{5}$ can be formed by the mixing of $B_{4}$ with $G_{15}$ or $G_{16}$, which are the ground waters near the south and north banks of Dousitu river respectively. But for the reactive species such as $\mathrm{Ca}^{2+}, \mathrm{HCO}_{3}^{-}$, $\mathrm{Mg}^{2+}$ and $\mathrm{SO}_{4}{ }^{2-}$, the relationships between their concentrations and TDS are irregular and can not be explained by the sole process of mixing. This indicates except mixing, these species have experienced some chemical reactions which makes their TDS-concentration relation orderless. Therefore, the key questions in explaining the chemistry of river water from $\mathrm{B}_{4}$ to $\mathrm{B}_{5}$ are: (1) calculation of the mixing proportion between $B_{4}$ and groundwater, (2) determination of the chemical reactions from $\mathrm{B}_{4}$ to $\mathrm{B}_{5}$ on the basis of above mixing.
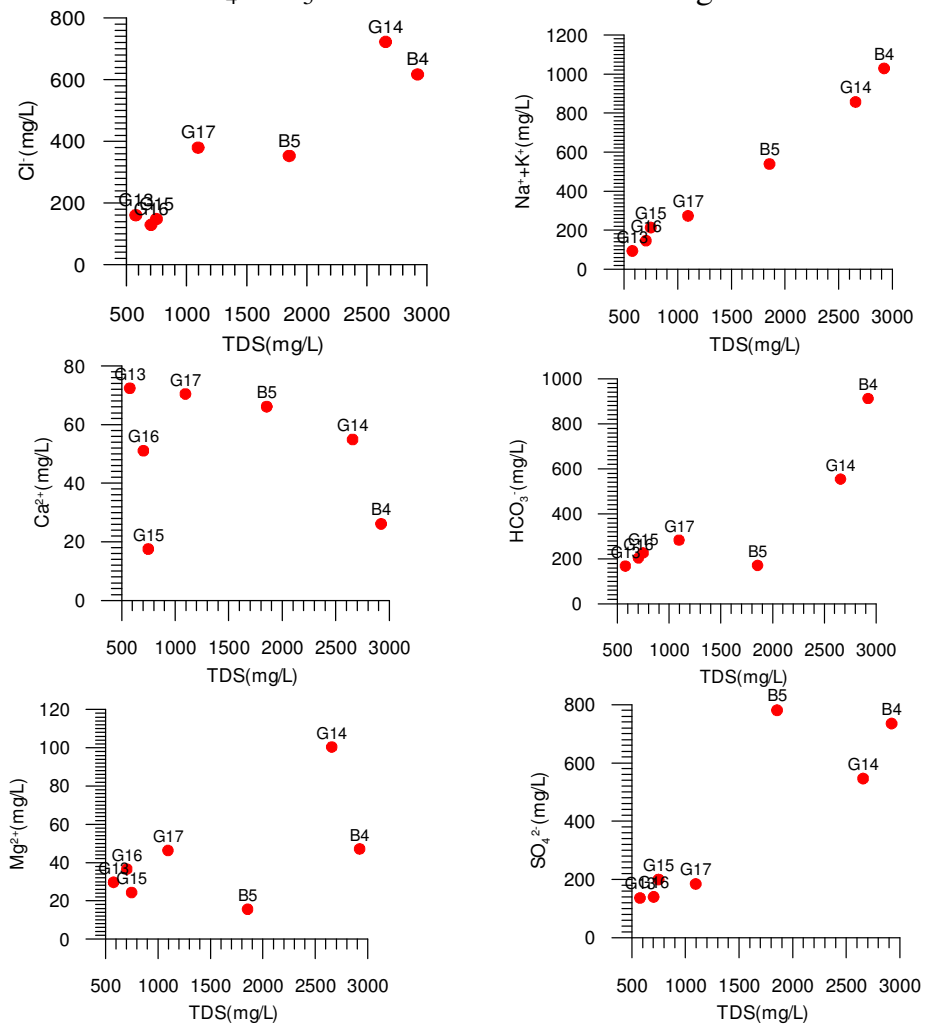

Figure 6. The relation between TDS and the concentrations of major ions

\section{Calculation of mixing proportion}

Now that the chemistry of river water in $\mathrm{B}_{5}$ is formed by both the processes of mixing and chemical reactions, and the chemical reactions affect little to the concentration of $\mathrm{Cl}^{-}$. So the mass balance of $\mathrm{Cl}^{-}$is used to calculate the mixing proportion. Let $p$ represent the mixing proportion of groundwater in river water from $\mathrm{B}_{4}$ to $\mathrm{B}_{5}$, then

$$
\mathrm{Cl}_{\mathrm{B} 5}=p \times \mathrm{Cl}_{\mathrm{G}}+(1-p) \times \mathrm{Cl}_{\mathrm{B} 4}
$$

Where, $\mathrm{Cl}_{\mathrm{B} 4}$ and $\mathrm{Cl}_{\mathrm{B} 5}$ represent the $\mathrm{Cl}^{-}$concentration of river water in $\mathrm{B}_{4}$ and $\mathrm{B}_{5}, \mathrm{Cl}_{\mathrm{G}}$ represents the $\mathrm{Cl}^{-}$concentration of groundwater. Using the $\mathrm{Cl}^{-}$concentration of groundwater 
$\mathrm{G}_{15}, \mathrm{G}_{16}$ and their average value, the mixing proportion of groundwater in river water from $\mathrm{B}_{4}$ to $\mathrm{B}_{5}$ can be calculated by equation (8). Table 4 lists the calculated mixing proportion and the corresponding composition of simply-mixed water. In the table, row $\mathrm{B}_{4}-\mathrm{G}_{15}, \mathrm{~B}_{4}-\mathrm{G}_{16}$ and $B_{4}-G_{\text {avg }}$ are the mixed results of $B_{4}$ with $G_{15}, G_{16}$, and $G_{\text {avg }}$, respectively. One thing should be noted is that $\mathrm{G}_{\text {avg }}$ is the simple half-and-half mixing of $\mathrm{G}_{15}$ and $\mathrm{G}_{16}$.

Table 4. Calculated mixing proportion and the corresponding concentrations of mixed waters (unit: $\mathrm{mg} / \mathrm{L}$ )

\begin{tabular}{ccccccccc}
\hline No. & P, \% & TDS & $\mathrm{Cl}^{-}$ & $\mathrm{Na}^{+}+\mathrm{K}^{+}$ & $\mathrm{Ca}^{2+}$ & $\mathrm{Mg}^{2+}$ & $\mathrm{SO}_{4}{ }^{2-}$ & $\mathrm{HCO}_{3}^{-}$ \\
\hline $\mathrm{B}_{4}$ & & 2922.74 & 616.80 & 1028.50 & 26.10 & 47.10 & 734.90 & 912.20 \\
$\mathrm{~B}_{4}-\mathrm{G}_{15}$ & 56.337 & 1697.75 & 352.70 & 561.13 & 21.27 & 34.26 & 433.45 & 526.00 \\
$\mathrm{~B}_{4}-\mathrm{G}_{16}$ & 54.158 & 1720.67 & 352.70 & 542.20 & 39.61 & 41.39 & 412.77 & 528.54 \\
$\mathrm{~B}_{4}-\mathrm{G}_{\text {avg }}$ & 55.226 & 1709.43 & 352.70 & 551.48 & 30.62 & 37.90 & 422.91 & 527.30 \\
$\mathrm{~B}_{5}$ & & 1854.52 & 352.7 & 538.65 & 66.10 & 15.60 & 780.50 & 170.90 \\
\hline
\end{tabular}

Table 4 shows when the mixing proportion based on mass balance of $\mathrm{Cl}^{-}$is used, the calculated concentration of $\mathrm{Na}^{+}+\mathrm{K}^{+}$for the 3 sets of mixed water equals approximately to that of river water in $\mathrm{B}_{5}$. This is because the property of $\mathrm{Na}^{+}+\mathrm{K}^{+}$is similar to $\mathrm{Cl}^{-}$and they all belong to the relatively non-reactive ions. But for the reactive species of $\mathrm{Ca}^{2+}, \mathrm{Mg}^{2+}, \mathrm{SO}_{4}{ }^{2-}$ and $\mathrm{HCO}_{3}{ }^{-}$, it is obviously improper to explain the chemistry of river water in $\mathrm{B}_{5}$ only by the simple process of mixing. Considering the hydrogeology and calculated saturation indices of minerals, the deviations between the simply-mixed water and $\mathrm{B}_{5}$ will be explained by the dissolution of gypsum and the precipitation of calcite and dolomite.

\section{Dissolution of gypsum}

According to the calculated results in Table 4, the concentration of $\mathrm{SO}_{4}{ }^{2-}$ in $\mathrm{B}_{5}$ should be 412.77 433.45 mg/L, if it were formed by the simple mixing. The actual concentration of $\mathrm{SO}_{4}{ }^{2-}$ in $\mathrm{B}_{5}$ is $780.5 \mathrm{mg} / \mathrm{L}$. Since the river water in $\mathrm{B}_{4}, \mathrm{~B}_{5}$ and the groundwater between them are all undersaturated with respect to gypsum (Table 1) and the Cenozoic group in the area is rich in gypsum, it is reasonable to think the extra $\mathrm{SO}_{4}{ }^{2-}$ comes from the dissolution of gypsum through the following reaction:

$$
\mathrm{CaSO}_{4} \cdot 2 \mathrm{H}_{2} \mathrm{O}=\mathrm{Ca}^{2+}+\mathrm{SO}_{4}{ }^{2-}+2 \mathrm{H}_{2} \mathrm{O}
$$

Using the calculated results in Table 4 , when the amounts of gypsum dissolved by the mixed water $\mathrm{B}_{4}-\mathrm{G}_{15}, \mathrm{~B}_{4}-\mathrm{G}_{16}$ and $\mathrm{B}_{4}-\mathrm{G}_{\mathrm{avg}}$ are $3.615(=(780.5-433.45) / 96), 3.831$ and $3.725 \mathrm{mmol} / \mathrm{L}$, respectively, the final results will be the concentration of $\mathrm{SO}_{4}{ }^{2-}$ in $\mathrm{B}_{5}$.

\section{Precipitation of calcite and dolomite}

The dissolution of gypsum introduced $\mathrm{Ca}^{2+}$ into the water, for the mixed water $\mathrm{B}_{4}-\mathrm{G}_{15}, \mathrm{~B}_{4}$ $\mathrm{G}_{16}$ and $\mathrm{B}_{4}-\mathrm{G}_{\text {avg }}$, the introduced $\mathrm{Ca}^{2+}$ are $144.60(=3.615 \times 40), 153.22$ and $149.00 \mathrm{mg} / \mathrm{L}$, respectively. Hence, the concentration of $\mathrm{Ca}^{2+}$ after mixing and dissolution of gypsum should be $165.87(=21.27+144.60), 192.83$ and $179.62 \mathrm{mg} / \mathrm{L}$, respectively. The actual concentration of $\mathrm{Ca}^{2+}$ in $\mathrm{B}_{5}$ is $66.10 \mathrm{mg} / \mathrm{L}$. The logical explanation for $\mathrm{Ga}^{2+}$ losses is the precipitation of calcite through the following reaction:

$$
\mathrm{Ca}+2 \mathrm{HCO}_{3}{ }^{-}=\mathrm{CaCO}_{3}+\mathrm{CO}_{2}+\mathrm{H}_{2} \mathrm{O}
$$

This is also in accordance with the calculated saturation indices of calcite in $\mathrm{B}_{4}$ and $\mathrm{B}_{5}$. It can be seen from equation (10) that with 1 mol precipitation of $\mathrm{Ca}^{2+}$, there will be $2 \mathrm{~mol}$ decrease of $\mathrm{HCO}_{3}{ }^{-}$in the solution. Therefore, for the mixed water $\mathrm{B}_{4}-\mathrm{G}_{15}, \mathrm{~B}_{4}-\mathrm{G}_{16}$, and $\mathrm{B}_{4^{-}}$ $\mathrm{G}_{\text {avg }}$, the concentration decreases of $\mathrm{HCO}_{3}{ }^{-}$caused by the precipitation of calcite are 304.31 $(=2 \times 61 \times(165.87-66.10) / 40), 386.53$ and $346.22 \mathrm{mg} / \mathrm{L}$, respectively. 
At the same time, compared with $15.6 \mathrm{mg} / \mathrm{L}$ of $\mathrm{Mg}^{2+}$ in $\mathrm{B}_{5}$, the concentration of $\mathrm{Mg}^{2+}$ in the mixed water is obviously too large. It will precipitate by dolomite just as $\mathrm{Ca}^{2+}$ in the manner of calcite. Using the similar method, the concentration decrease of $\mathrm{HCO}_{3}{ }^{-}$caused by the precipitation of dolomite for the mixed water $B_{4}-G_{15}, B_{4}-G_{16}$ and $B_{4}-G_{\text {avg }}$ are 94.86 $(=2 \times 61 \times(34.26-15.60) / 24), 131.10$ and $113.36 \mathrm{mg} / \mathrm{L}$, respectively.

It can be seen from the above discussion that the concentration of $\mathrm{HCO}_{3}{ }^{-}$in the mixed water of $\mathrm{B}_{4}-\mathrm{G}_{15}, \mathrm{~B}_{4}-\mathrm{G}_{16}$ and $\mathrm{B}_{4}-\mathrm{G}_{\mathrm{avg}}$ should be 570.07 (170.90+304.31+94.86), 688.53 and $630.48 \mathrm{mg} / \mathrm{L}$, respectively if the dissolution of gypsum and the precipitation of calcite and dolomite were not happened after the mixing of $\mathrm{B}_{4}$ with groundwater.

\section{Restored results}

In this paper, the restored concentration is defined as the concentration of mixed water without chemical reactions or before chemical reactions which can get the concentration of $\mathrm{B}_{5}$ after the chemical reactions happens. According to the above calculation, the restored concentration of $\mathrm{HCO}_{3}{ }^{-}$is a little lager but close to the simply-mixed (Table 4). The reason for this is the precipitation of calcite may not completely follow the stoichiometric relationship of equation (10), some $\mathrm{CO}_{2}$ produced in reaction (10) may dissolve into water and not release to the atmosphere. So the decrease of $\mathrm{HCO}_{3}^{-}$calculated using the stoichiometric relationship of equation (10) may be a little larger, which leads to the larger calculated concentration of $\mathrm{HCO}_{3}{ }^{-}$.

Here the restored $\mathrm{B}_{5}$ (represented by $\mathrm{B}_{5}{ }^{\prime}$ ) based on $\mathrm{B}_{4}-\mathrm{G}_{\text {avg }}$ is taken as an example to show the results. In Figure 7, the restored concentration of $\mathrm{HCO}_{3}{ }^{-}$is drawn against TDS. In this case, $\mathrm{B}_{5}{ }^{\prime}$ has already on the line drawn through $G_{15}, G_{16}$ and $B_{4}$, which indicates the mixing of $B_{4}$ with the average mixture of $G_{15}$ and $G_{16}$ can form the chemistry of river water in $B_{5}$ through the following processes: (1) mixing of $44.77 \% \mathrm{~B}_{4}$ and $55.23 \% \mathrm{G}_{\text {avg }}$; (2) the $3.725 \mathrm{mmol} / \mathrm{L}$ dissolution of gypsum; (3) the precipitation of calcite and dolomite by the amounts of 346.22 and $113.36 \mathrm{mg} / \mathrm{L}$, respectively. This process also shows from $\mathrm{B}_{4}$ to $\mathrm{B}_{5}$, at least $55 \%$ of river water is from groundwater.

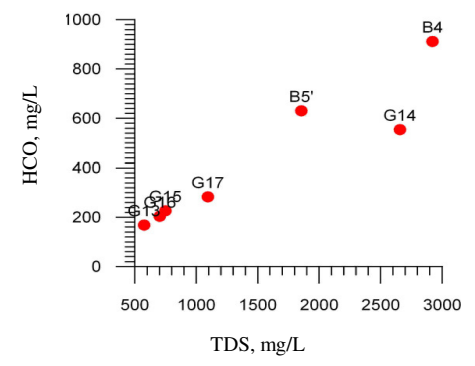

Figure 7. The relation between TDS and the restored $\mathrm{HCO}_{3}{ }^{-}$

\section{Conclusion}

In the middle section of Dousitu River, the changes of the chemistry of river water are great. The TDS of the river water increases from $\mathrm{B}_{3}$ to $\mathrm{B}_{4}$ and decreases from $\mathrm{B}_{4}$ to $\mathrm{B}_{5}$. The concentration of $\mathrm{Cl}^{-}, \mathrm{Na}^{+}, \mathrm{K}^{+}, \mathrm{Mg}^{2+}$ and $\mathrm{HCO}_{3}^{-}$has a similar change with TDS, but the concentration of $\mathrm{Ca}^{2+}$ and $\mathrm{SO}_{4}{ }^{2-}$ increases steadily. The hydrochemical types of the river water change from $\mathrm{HCO}_{3} \bullet \mathrm{Cl}-\mathrm{Na}$ type to $\mathrm{Cl} \bullet \mathrm{SO}_{4} \bullet \mathrm{HCO}_{3}-\mathrm{Na}$ type and finally to $\mathrm{SO}_{4} \bullet \mathrm{Cl}-\mathrm{Na}$ type.

The chemistry of river water in $\mathrm{B}_{4}$ is formed by the conjunctive processes of evaporation and chemical reaction. Evaporation is the main process, which makes the concentration of species increase by about 3.5 times. The main chemical reactions forming the chemistry of river water in $\mathrm{B}_{4}$ are dissolution of halite and gypsum, the precipitation of calcite and degassing of $\mathrm{CO}_{2}$. Cation exchanges between $\mathrm{K}^{+}-\mathrm{Na}^{+}, \mathrm{Ca}^{2+}-\mathrm{Na}^{+}$and $\mathrm{Ca}^{2+}-\mathrm{Mg}^{2+}$ also play some roles. 
The concentrations of non-reactive species in $\mathrm{B}_{5}$ can be explained by the simple mixing process. But for the reactive species, chemical reactions occurred between $\mathrm{B}_{4}$ and $\mathrm{B}_{5}$ have distinct effects on their concentrations. Mass balance of $\mathrm{Cl}^{-}$shows the river gets more than $50 \%$ of groundwater recharge between $\mathrm{B}_{4}$ and $\mathrm{B}_{5}$. On the basis of mixing, the dissolution of gypsum, precipitation of calcite and dolomite and the degassing of $\mathrm{CO}_{2}$ also play important roles in forming the chemistry of river water in $\mathrm{B}_{5}$.

The formation processes of the chemistry of river water in $\mathrm{B}_{4}$ indicate that when a reservoir is built in an arid area, the loss of water resources due to evaporation is huge, and making things worse, the evaporation can also lead to the degradation of water qualities. Hence, great care should be taken to build a reservoir in arid and semi-arid regions.

\section{Acknowledgment}

This research was supported by the projects of National Natural Scientific Foundation of China (40772160, 40372114). The authors are grateful to senior engineer Hou Guangcai from Xi' an Institute of Geology and Mineral Resources for his help in field and indoor study. Special thanks to senior engineers Liu Junting and Hou Jianjun from the Geological Survey of Inner Mongolia Autonomous Region, they gave us much help in our field study. Authors also would like to thank the editor and anonymous reviewers for their valuable comments that have greatly improved the quality of the article.

\section{References}

1 Ronald J. Gibbs, Geochimica et Cosmochimica Acta, 1972, 36(9), 1061-1066.

2 Rothwell J J, Dise N B and Taylor K G, Allott T E H, Scholefield P, Davies H and Neal C, Science of the Total Environ., 2010, 408(4) 841-855.

3 Smolders A J P, Hudson-Edwards K A and Van der Velde G, Roelofs J G M, Appl Geochem., 2004, 19(11), 1745-1758.

4 Van Kleef Hein H, Emiel Brouwer and Rob S E W Leuven, Van Dam Herman, De VeriesBrock Ankie, Van Der Velde Gerard, Esselink Hans, Environ Pollut., 2010, 158(8), 2679.

5 Ian Donohue, Martin L. McGarrigle and Paul Mills, Water Res., 2006, 40(1), 91-98.

6 Ahearn D S, Sheibley R W, Dahlgren R A and Keller K E. J Hydrol., 2004, 295(1-4), 47-63.

$7 \quad$ Négrel P and Lachassagne, P, J Hydrol., 2000, 237, 212-233.

8 Sobieraj J A, Elsenbeer H and McClain, M, Hydrocycl Proc., 2002, 16, 1353-1372.

9 Qian H, Dou Y, Li X J, Yang B C and Zhao Z H, Hydrogeology and Engineering Geology, 2007, 34(1), 107-112 (in Chinese).

10 Qian H, Li M Y, Ji Y D, Yang B C and Zhao Z H, Aquatic Geochem., 2007, 13(2), 127-142

11 Li Y F, Wan W F, Wu Y G, Qu H and Hou G C, Environ Geol., 2006, 49(3), 430-436.

12 Xie Y, Wang J, Yin Y P, Wu X M, Wen D G, Jiang X S, Luo J N, Wei L W, li M H and Zheng W M, Geological Bulletin of China, 2003, 22(10), 819-828 (in Chinese).

13 Li Y F, Xu Z H and Wang J X, Environmental Geology, 2005, 47(5), 647-652.

14 Wang J X, Li Y F and X B, Proceedings of the International Conference on Information Technology and Environmental Systems Sciences in 2008, Henan, China, 4, 484-488.

15 Hou G C, Liang Y P, Yin L H, Tao Z P, Zhao Z H, Yang X C and Wang X Y, Hydrogeology and Engineering Geology, 2009, 36(1), 18-23 (in Chinese).

16 Hou G C, Lin X Y and Su X S, Wang X Y and Liu J, J Jilin University (Earth Science Edition), 2006, 36(3), 391-398 (in Chinese).

17 Xie Y, Wang J, Jiang X S, Li M H, Deng G S, Hou G C, Liu F, Wang D Q, Sun Y M, Zhu H, Wang Y H and Luo J N, Hydrogeol Eng Geol., 2005, 32(2), 11-19 (in Chinese).

18 Li Y F, Feng J G, Wang W, Li J R, Wang J X, Xu Z H and Li Y, Northwestern Geology, 2004, 37(1), 90-96 (in Chinese).

19 Yang Y, Chang W, Hou G C, Wang Y H and Zhang P B, Acta Sedimentologica Sinica, 2006, 24(3), 387-393 (in Chinese). 


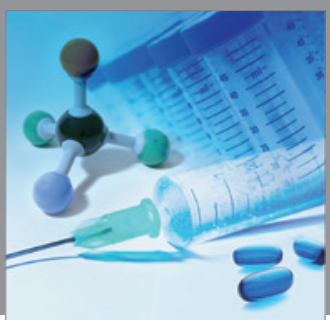

International Journal of

Medicinal Chemistry

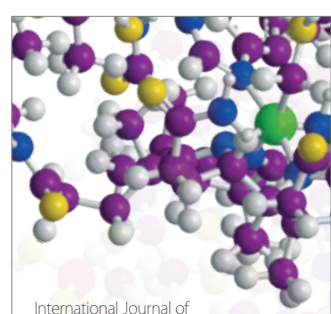

Carbohydrate Chemistry

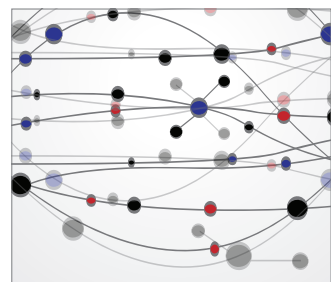

The Scientific World Journal
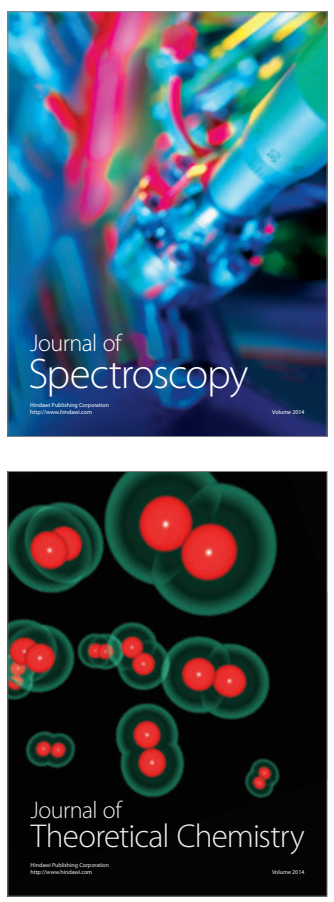
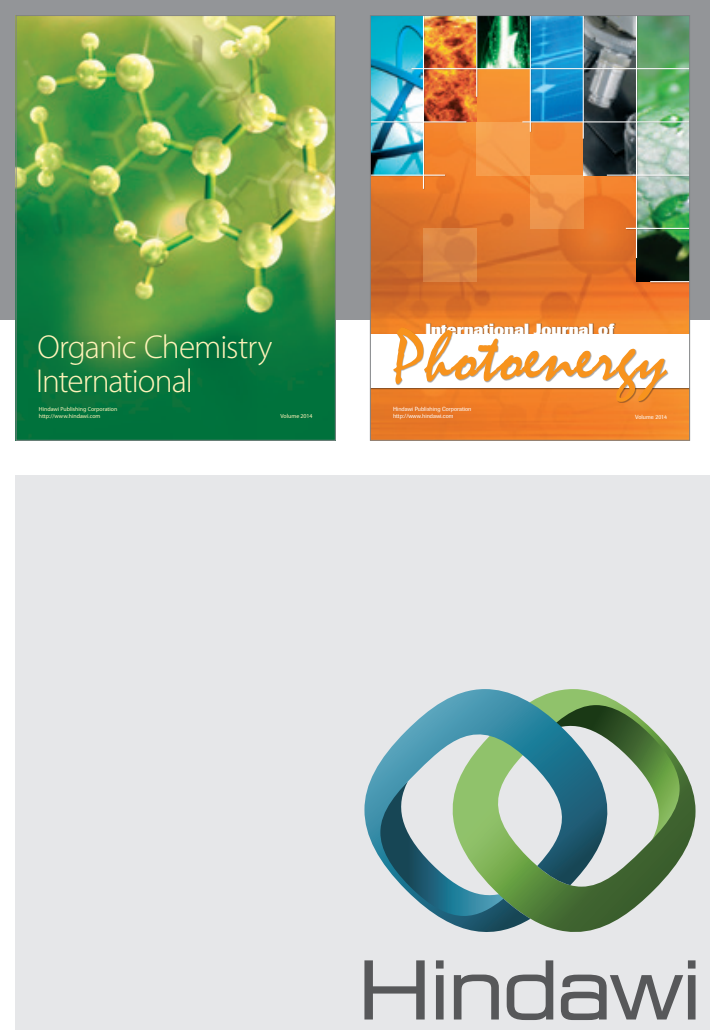

Submit your manuscripts at

http://www.hindawi.com
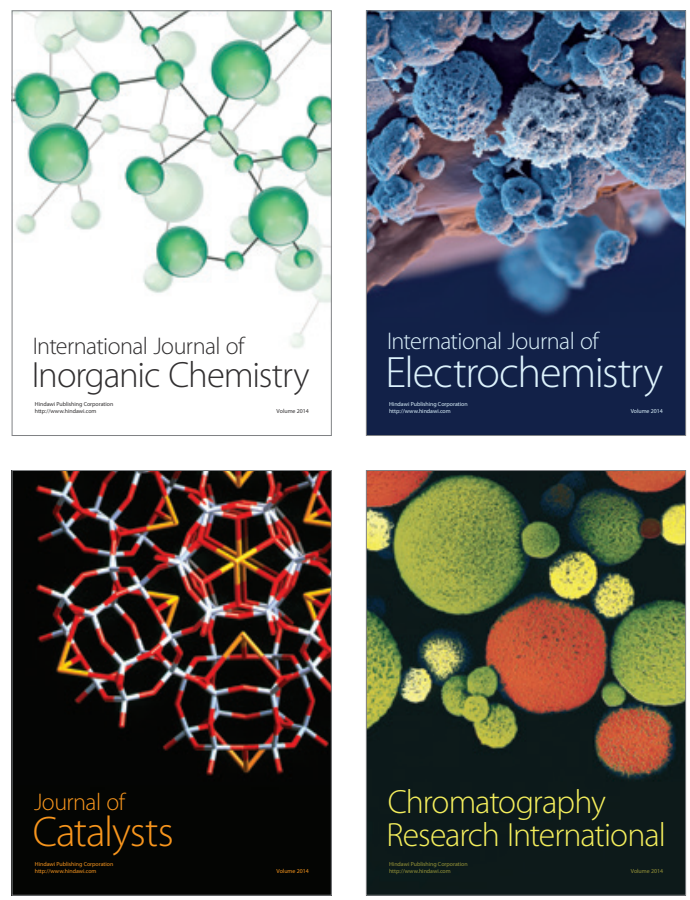
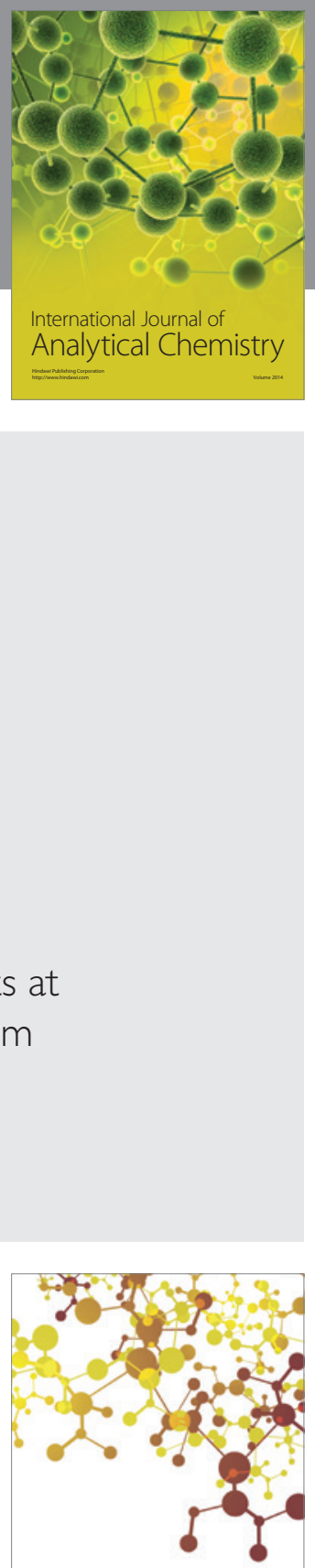

Journal of

Applied Chemistry
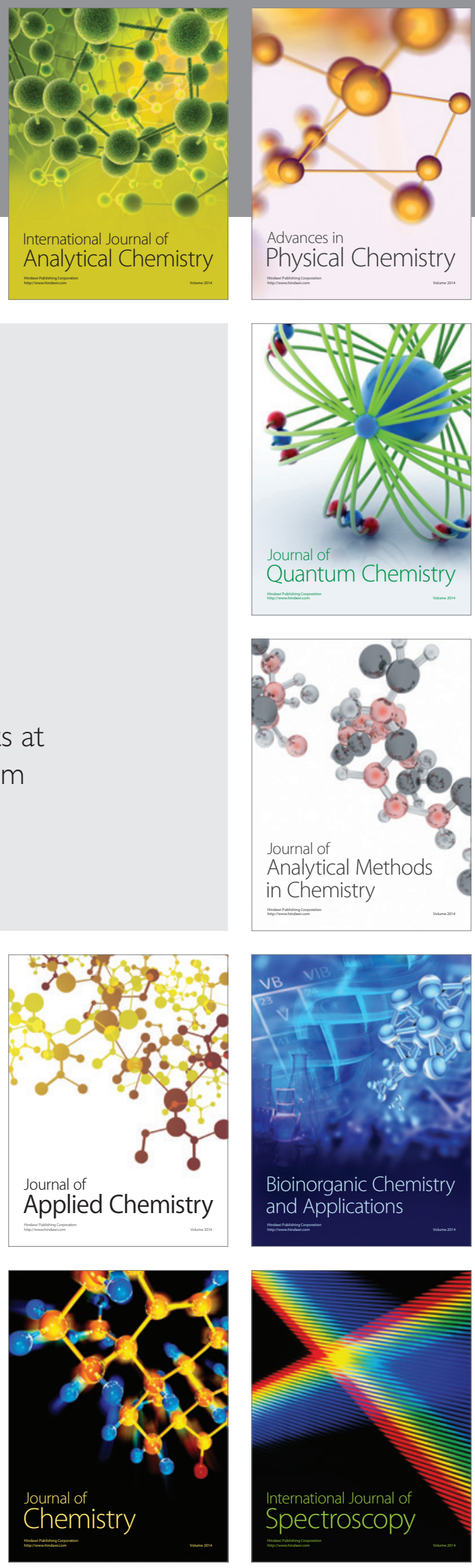